\title{
酸化ニッケル-酸化タングステン-アルミナ触媒による エチレンとプロピレンの共二量化反応
}

(1972 年 9 月 6 日 受理)

小林 厚夫 夫越後谷 悦 郎*

担体付の $\mathrm{NiO}, \mathrm{WO}_{3}, \mathrm{NiO}-\mathrm{WO}_{3}$ 触媒上で, エチレンとプロピレンの共二量化反応を行ない, シリ カおよびアルミナの担体効果と共二量化反応の機構を推察した。反応は常圧, 固定層流通系で行なっ た。 $\mathrm{NiO}-\mathrm{WO}_{3}-\mathrm{Al}_{2} \mathrm{O}_{3}$ 触媒が共二量化反応に有効であり, $\mathrm{NiO}-\mathrm{Al}_{2} \mathrm{O}_{3}$ より活性が大きかった。また, $\mathrm{WO}_{3}-\mathrm{Al}_{2} \mathrm{O}_{3}$ 上では共二量化反応は起こらなかった。また生成物の異性化反応も合わせて検討し, 共二 量化反応による一次生成物は $n$-ペンテン（1または 2 ）であり, イソペンテンは $n$-ペンテンの異性化 によるものと結論した。

また, エチレン, プロピレンの各種触媒に対する反応性は

$$
\begin{aligned}
& \text { エチレン: } \mathrm{NiO}-\mathrm{WO}_{3}-\mathrm{Al}_{2} \mathrm{O}_{3}>\mathrm{NiO}-\mathrm{Al}_{2} \mathrm{O}_{3} \gg \mathrm{WO}_{3}-\mathrm{Al}_{2} \mathrm{O}_{3} \approx 0 \\
& \text { プロピレン: } \mathrm{NiO}-\mathrm{WO}_{3}-\mathrm{Al}_{2} \mathrm{O}_{3}>\mathrm{WO}_{3}-\mathrm{Al}_{2} \mathrm{O}_{3}>\mathrm{NiO}-\mathrm{Al}_{2} \mathrm{O}_{3}
\end{aligned}
$$

であった。

またこれらの触媒は二量化活性ばかりでなく，異性化活性も有し，とくに $\mathrm{NiO}-\mathrm{Al}_{2} \mathrm{O}_{3}, \mathrm{NiO}-\mathrm{WO}_{3}-$ $\mathrm{Al}_{2} \mathrm{O}_{3}$ は二重結合の異性化能が大きく，生成物はほとんぞ平衡組成に近かった。

\section{1 粕 言}

固体触媒を用いてのオンフィンの二量化反応の研究には多くの 埌告がある。Shultzら ${ }^{12) 2}$ は, 酸化コバルトーカーボン上でのオレ フィンの二量化に対して， $\pi$-錯体中間体を提示している。尾崎 ら゙)は, ニッケルーシリカを用いてェチレンの二量化とブテンの異 性化との関係を詳細に述べている。また井, 内田ら")は酸化夕 ソグステンーシリカアルミナ上でのプロピレンの二量化反応を, シクロブタシ中間体で説明した。このように, 二量化反応につい ては多くの研究報告があるが，共二量化反応についてははとんど ない,5)。

本報では，酸化ニッケル-酸化タングステンーアルミナ触媒を用 いて，エチレンとプロピレンの共二量化反応を行なったところ， この触媒が共二量化反応に有効であることを見いだしたので，こ の反応に対する触媒担体の影響, 反応生成物分布, 扣よび生成物 の異性化反応などを合わせて考察し，その反応機棈を推察した。

* 東京工業大学工学部化学工学科, 東京都目黒区大岡山

1) R. G. Shultz, R. M. Engelbrecht, R. N. Moore, L. T. Wolford, J. Catal., 6, 419(1966).

2) R. G. Shultz, J. M. Schuck, B. S. Wildi, ibid., 6, 385 (1966).

3) K. Kimura, H. Ai, A. Ozaki, ibid., 18, 271(1970).

4) H. Imai, T. Hasegawa, H. Uchida, Bull. Chem. Soc. Jap., 41, 45(1968).

5) T. Amemiya, Proceeding of the seventh World Petroleum Congress, 9 34(1967).

6) K. Takahashi, H. Ohtsuka, N. Yoneda, Bull. Jap. Petro. Institute, 13, No. 1(1971).
2 実験

\section{1 反応装置および反応操作方法}

本実験で用いた反応装監は，通常の固定層流通反応装䁂で常压 で行なった。原料ガスのエチレンおよびプロピレン，また処理ガ スの高純度窒素は，いずれもシリカゲル乾燥塔で乾燥精製された のち，混合され流動浴中に設置した内径 $8 \mathrm{~mm}$ のパイレックス反 応管に送られる。反応前につぎのよらな処理を行なった。

室温で反応系内を高純度窒素で膡换したのち，窒素を $100 \mathrm{ml}$ $\min$ の流速で触媒層に通しながら, 処理温度の $400^{\circ} \mathrm{C}$ ま卡 し，2 時間この温度でたもったのち，所定の反応温度まで温度を 下げ，反応を開始した。本実験中寸べての実験に対して上記のよ らな同一の前処理を行なった。触媒量は $10 \mathrm{ml}$ とし，一定量を使 用した。

\section{2 分 析}

反応生成物の分析は，ガスクロマトグラフィーを用いて行なっ た。分離カラムは, 内径 $4 \mathrm{~mm}$ の銅パイプに, テトラェチレング リコールージメチルエーテルをセライトトに $10 \mathrm{wt} \%$ 担持した多 のを充テンして用い, エチレン, プロピレン, $n$-ブテン扰よび ペンテン類は $13.5 \mathrm{~m}$ のカラムを用いて分析し，それぞれ半值幅 法により求め、へキセン類は $7 \mathrm{~m}$ のカラムを用い，全面䖽を計算 し異性体の分析は行なわなかった。またイソブテンと 1-ブテン の分析には，10 wt \% のベンジルシアナイド硝酸銀を Neopack $1 \mathrm{~A}$ に担持した $8 \mathrm{~m}$ のものを用い室温で分析した。それでれキ ヤリヤーガスは水素で，流速 $50 \mathrm{ml} / \mathrm{min}$ の条俳で分析した。

2.3 試 料

原料として用いたエチレンの純湛は $99.5 \%$ ，プロピレンは 
Table 1 The composition and surface area of catalysts and the treatment condition

\begin{tabular}{|c|c|c|c|c|c|c|}
\hline No. & $\mathrm{Ni} / \mathrm{W}^{a)}$ & $(\mathrm{Ni}+\mathrm{W}) / \mathrm{Al}^{b)}$ & Carrier & $\begin{array}{l}\text { Calcined } \\
\text { temp. } \\
\left({ }^{\circ} \mathrm{C}\right)\end{array}$ & $\begin{array}{c}\text { Calcined } \\
\text { time } \\
(\mathrm{hr})\end{array}$ & $\begin{array}{c}\text { Surface } \\
\text { area } \\
\left(\mathrm{m}^{2} / \mathrm{g}\right)\end{array}$ \\
\hline Cat 01 & - & - & - & 600 & 11 & 178 \\
\hline Cat 02 & - & - & - & 700 & 11 & 134 \\
\hline Cat 03 & - & - & - & 800 & 11 & 111 \\
\hline Cat 04 & - & - & - & 900 & 11 & 95 \\
\hline Cat 05 & - & - & - & 1000 & 11 & 57 \\
\hline Cat 06 & - & - & - & 1100 & 11 & 6 \\
\hline Cat $\left.07^{c}\right)$ & - & - & - & 600 & 11 & - \\
\hline Cat 11 & - & $5 / 95$ & Cat 01 & 500 & 5 & 170 \\
\hline Cat 12 & $3 / 1$ & $5 / 95$ & $\prime \prime$ & 500 & 5 & 170 \\
\hline Cat 13 & 1 & $5 / 95$ & $" \prime$ & 500 & 5 & 170 \\
\hline Cat 14 & $1 / 3$ & $5 / 95$ & $" \prime$ & 500 & 5 & 173 \\
\hline Cat 15 & 0 & $5 / 95$ & $" 1$ & 500 & 5 & 146 \\
\hline Cat 21 & 1 & $5 / 95$ & Cat 02 & 500 & 5 & 146 \\
\hline Cat 22 & 1 & $5 / 95$ & Cat 03 & 500 & 5 & 110 \\
\hline Cat 23 & 1 & $5 / 95$ & Cat 04 & 500 & 5 & 90 \\
\hline Cat 24 & 1 & $5 / 95$ & Cat 05 & 500 & 5 & 51 \\
\hline Cat 25 & 1 & $5 / 95$ & Cat 06 & 500 & 5 & 6 \\
\hline Cat 26 & 1 & $5 / 95$ & Cat 07 & 500 & 5 & 169 \\
\hline
\end{tabular}

$a), b)$ Atom ratio. c) $\mathrm{SiO}_{2}$.

Cat $01 \sim$ Cat 06 show $\mathrm{Al}_{2} \mathrm{O}_{3}$.

$4.2 \%$ のプロパンを含むものを用いた。

\section{4 担体および触媒の調製}

2.4.1 担 体

（1）アルミナ：日産化学製のアルミナゾル（約 $10 \mathrm{wt} \%)$ を 湯浴上で十分に乾燥じ，空気中で所定の温度で焼成したのち，32 〜60 メッシュにそろえた。担体の焼成は $600 \sim 1100^{\circ} \mathrm{C}$ の範团で それぞれ一定温度で 11 㭙間行なった。以下 $600^{\circ} \mathrm{C} て ゙$ 焼成したも のを $\mathrm{Al}_{2} \mathrm{O}_{3}$ (600) と記す。

（2）シリカ：日産化学製のスノーテックス0（約 $20 \mathrm{wt} \%$ ) を上記のアルミナと同様の条件で調製した。

\section{4 .2 触媒の調製}

（1） $\mathrm{NiO}-\mathrm{Al}_{2} \mathrm{O}_{3}$ 触媒：アルミナ（600）を所定の濃度の硝酸 ニッケル水溶液に浸漬し、これを蒸発乾固し乾燥後 $500^{\circ} \mathrm{C}$ で 5 時 間空気気流中で焼成し、デシケーター中に保存した。

(2) $\mathrm{WO}_{3}-\mathrm{Al}_{2} \mathrm{O}_{3}$ 触媒 : アルミナ (600) を担体とし，パラタ ングステン酸アンモニウム水溶液を 2.4.2（1）で示した同様の 方法で調製する。

(3) $\mathrm{NiO}-\mathrm{WO}_{3}-\mathrm{Al}_{2} \mathrm{O}_{3}$ 触媒：各種焼成温度のアルミナを担体 として用い, はじめにパラタングステン酸アンモニウムの水溶 液，つぎに硝酸ニッケル水溶液を用いて 2.4.2（1）と同様の方 法で調製した。な拈担体に対する担持金属酸化物の原子比を表 1 に示す。

\section{5 触媒の表面栍}

担体を含む触媒の全表面積は，通常の BET 法により測 定し た。表1にその佔を示す。

\section{3 結果および考察}

3.1 エチレンとプロピレンの共二量化反応

3.1 .1 担体の効果: 酸化ニッケルと酸化タングステンの原子 比を $1: 1$ にまた $(\mathrm{Ni}+\mathrm{W}) / \mathrm{Al}=1 / 19$ (シリカの場合は $(\mathrm{Ni}+\mathrm{W}) /$ $\mathrm{Si}=1 / 19)$ と一定にし，橴成温度を变えた各種アルミナおよびシ リカを担体として反応を行なった。各触媒の反応 1 時間半後の活
性比較を図 1 亿示す。 $600^{\circ} \mathrm{C}$ で焼成したアルミナがすっとす活性 が大きく，またペンテンの収率がよい。 $1100^{\circ} \mathrm{C} て ゙$ 焼成したすの については，ほとんど活性がない。表 1で示したよらに焼成温度 が高くなるにつれて表面積が小さくなっており，単位面積あたり に換算すれば，活性はほぼ等しい。しかし、シリカ担体の場合の 活性と，アルミナ担体の活性を比较 (Cat 26 と Cat 13) するど, 表面積がほとんど同じにもかかわらず，アルミナ担体の方が活性 が大きい。またアルミナの焼成温度を変えた場合，それぞれの選 択率が大きく変わっている（図 1-b, c, d)。このことから，フル ミナは単に表面積を大きくするたけでなく，活性点の性質を大き く変えていることがわかるが，その原因は明らかでない。以後の 実験では，もっとも活性が大きく，またペンテンの収率のよかっ た $\mathrm{Al}_{2} \mathrm{O}_{3}(600)$ を担体として用いた。

$3.1 .2 \mathrm{Ni} / \mathrm{W}$ 原子比の影響: 触媒は, $(\mathrm{Ni}+\mathrm{W}) / \mathrm{Al}=1 / 19$ の ものを用い，担体としては3.1.1で示したようにもっとも活性 の大きかった $\mathrm{Al}_{2} \mathrm{O}_{3}(600)$ を用いた。結果を図 2 に示す。酸化二 ッケルあるいは酸化タングステンたけをアルミナに担持したるの を用いるよりも，両金属酸化物を担持したるのの方が活性が大き い。これは，両金属酸化物を加えることにより，新しい活性点の 生成あるいは増加が考えられる。とくに Ni/W=1/3 のとき活性 が大きかった。つぎに選択率や，生成モル分率については，タン グステンの原子比が増加するにつれて, ブテン中のイソブテン, ペンテン中のイソペンテンが増加する。しかしブテン中の $n$-ブ テン, ペンテン中の $n$-ペンテン間, またイソペンテン間の生成 モル比はほとんど平衡值に近い。さらに全ブテン, 全ペンテン間 では，イソ体が少なく全体の平衡值よりはるかにはなれている。 これらの結果から, 重合活性以外に二重結合の異性化活性す有す ると思われる。骨格異 性 化活性は，二重結合の異性化速度にく らべてはるかに遅いと思われる。

また四 2 で示した転化率において，点線は生成物からつぎのよ らにして求めた。 


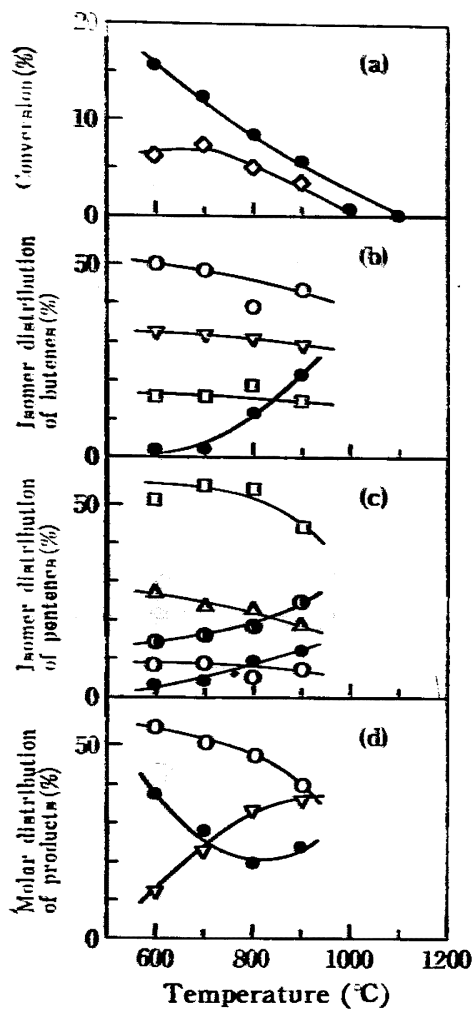

Fig. 1 The effect of calcined temperature of carrier on activity and selectivity

Catalyst : $\mathrm{Ni}: \mathrm{W}: \mathbf{A l}(\mathrm{Si})=2.5: 2.5: 95$

Catalyst volume $: 10 \mathrm{ml}$, Feed rate $: 30 \mathrm{ml} / \mathrm{min}$, Mole ratio of reactants : $\mathrm{C}_{2} \mathrm{H}_{2} / \mathrm{C}_{3} \mathrm{H}_{6}=1$, Reaction temperature : $200^{\circ} \mathrm{C}$ (a) : Conversion

(b) : Butenes

: Ethylene, $\diamond:$ Propylene

글 : 1-Butene, $O$ : trans-2-Butene, $\nabla$ : cis-2-Butene,

: Isobutene

(c) : Pentenes

$O:$ 1-Pentene, $\square$ : trans-2-Pentene, $\triangle$ : cis-2-Pentene, : 2-Methyl-1-butene, $0: 2$-Methyl-2-butene (d) :

$O:$ Butenes, $:$ Pentenes, $\nabla:$ Hexenes

$$
\begin{aligned}
& \mathrm{C}_{2} \mathrm{H}_{4} \text { conv. }=\frac{\mathrm{C}_{4} \mathrm{H}_{8} \times 2+\mathrm{C}_{5} \mathrm{H}_{10}}{\mathrm{C}_{2} \mathrm{H}_{4}+\mathrm{C}_{4} \mathrm{H}_{8} \times 2+\mathrm{C}_{5} \mathrm{H}_{10}} \times 100 \\
& \mathrm{C}_{3} \mathrm{H}_{6} \text { conv. }=\frac{\mathrm{C}_{6} \mathrm{H}_{12} \times 2+\mathrm{C}_{5} \mathrm{H}_{10}}{\mathrm{C}_{3} \mathrm{H}_{6}+\mathrm{C}_{6} \mathrm{H}_{12} \times 2+\mathrm{C}_{5} \mathrm{H}_{10}} \times 100
\end{aligned}
$$

実線は，エチレンとブロピレンそれそれの二量化反倇の生成物 分布を考虑して求めた结果である。ニッケルを含む 4 種の虫媒で はよく一致するが WO ンテンの異性体分布, およびブテン, ペンテン, へキセンへの生 成モ几分布す $\mathrm{WO}_{3}-\mathrm{Al}_{2} \mathrm{O}_{3}$ の場合はいちじるしく異なっている。 $\mathrm{WO}_{3}-\mathrm{Al}_{2} \mathrm{O}_{3}$ による結果は，後の 3.2 のところで述べる。

3.1.3 接触時间の影雾：生成物であるペンテンがェチレンと ブロピレンの共二量化で生成しているかどらかを，接触時間を变 えて反底を行ない調へた。結果を図3に示す。生成したブテン, ペンテン，人キセンの生成モル比はほとんど一定である。このこ とからペンテンは，エチレンとプロピレンの共二量化によって生 成していると考えられる。またへキセンの生成モル分率が接触時

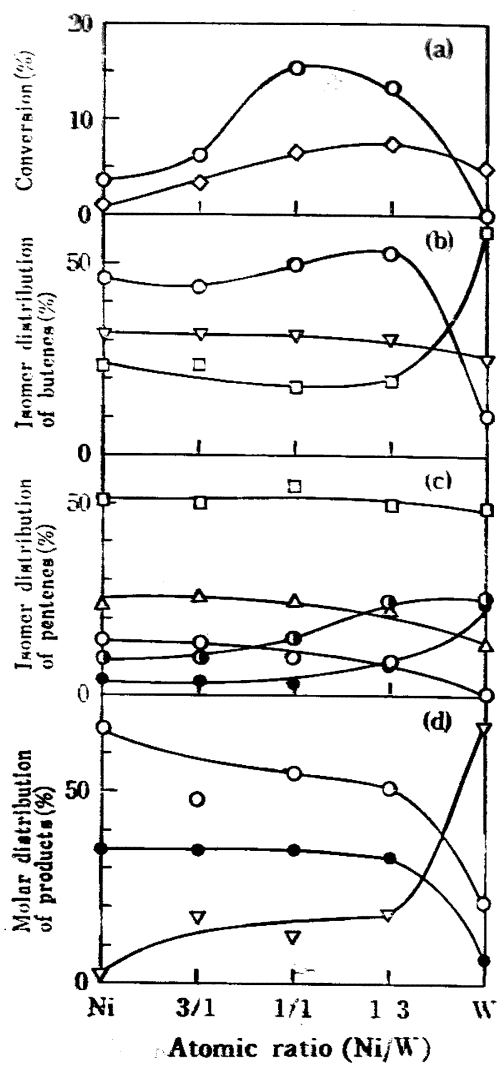

Fig. 2 The effect of catalyst composition on conversion and selectivity

Catalyst : $(\mathrm{Ni}+\mathrm{W}): \mathrm{Al}=5: 95$, Catalyst volume $: 10 \mathrm{~m} l$, Feed rate: $30 \mathrm{ml} / \mathrm{min}$, Mole ratio of reactants : $\mathrm{C}_{2} \mathrm{H}_{4}$ $\mathrm{C}_{\mathbf{s}} \mathrm{H}_{\mathbf{6}}=1$, Reaction temperature $: 200^{\circ} \mathrm{C}$

(a) : Conversion

$$
\bigcirc \text { : Ethylene, } \diamond: \text { Propylene }
$$

(b) : Butenes

$$
\begin{aligned}
& \square: \text { 1-Butene and Isobutene, } O \text { :trans-2-Butene, } \\
& \nabla: \text { cis-2-Butene }
\end{aligned}
$$

(c) : Pentenes

$O:$ 1-Pentene, $\square$ : trans-2-Pentene, $\triangle:$ cis-2-Pentene, : 2-Methyl-1-butene, : 2-Methyl-2-butene (d):

$O:$ Butenes, $:$ Pentenes, $\nabla:$ Hexenes

間の増加とともにわずかに増しているのは，エチレンの三量化に よるるのと思われる。また、ペンテンの異性体分布が汪とんと変 わらないことから、ペンテンの異性化の速度か速く、すみやかに 平畣に達していることがかかる。

3.1 .4 反応温度の影幚: Cat 13 を用いて, 反応温度を 200〜 $390^{\circ} \mathrm{C}$ の範围で变え，生成物の分布を調へた。結果を図 4 に示す。 ブテン, ベンテンともに, 直鎖のものが反応温度の増加とともに 減少し，イッ体が增加する。とくにヘンテンについては，200 で $18^{\circ}$ 。 であったインペンテンが $390^{\circ} \mathrm{C} て ゙ は 61^{\circ}$ 。 まで増加して いる。この点についてはのちに生成物の異性化のところで検討す る。

\section{2 エチレンおよびブロビレンの二貫化反応}

ニッケルータングステンーアルミナ触媒が，エチレンとプロピレ ンの共二量化反応に活珄であることを示したが，とくに WO $\mathrm{Al}_{2} \mathrm{O}_{3}$ では，他のニッケルを含む蝶媒と比較して生成物分布が大 


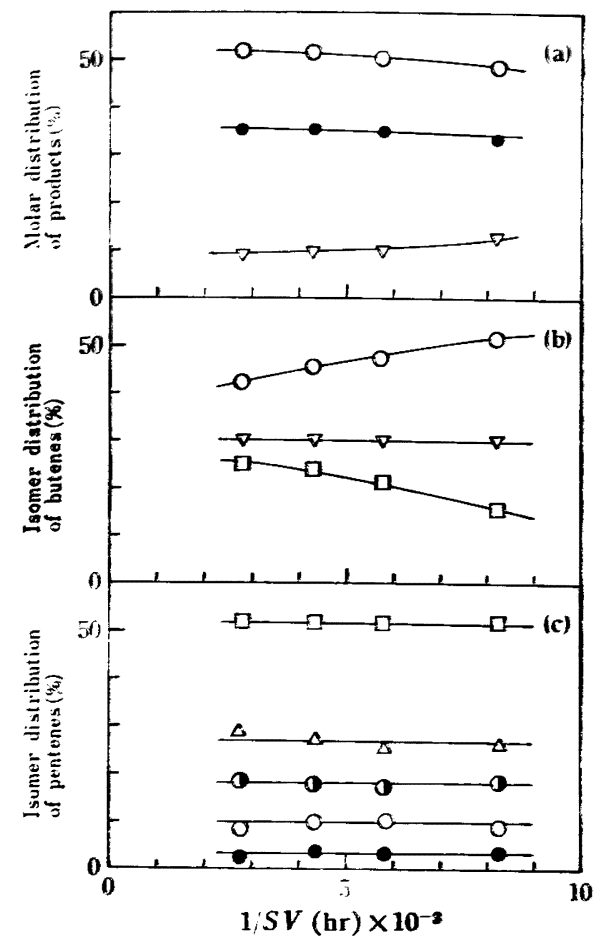

Fig. 3 The effect of the contact time on molar distribution and isomer distributions of products

Catalyst : $\mathrm{Ni}: \mathrm{W}: \mathbf{A l}=2.5: 2.5: 95$, Catalyst volume : $10 \mathrm{ml}$, Feed rate : $30 \mathrm{ml} / \mathrm{min}$, Molar ratio of reactants : $\mathrm{C}_{2} \mathrm{H}_{4} / \mathrm{C}_{3} \mathrm{H}_{6}=1$

(a):

$O:$ Butenes, : Pentenes, $\nabla:$ Hexenes

(b) : Butenes

$\square: 1-B u t e n e$ and isobutene, $O$ :trans-2-Butene, $\nabla:$ cis-2-Butene

(c) : Pentenes

$O$ : 1-Pentene, $\square$ : trans-2-Pentene, $\Delta$ : cis-2-Pentene, : 2-Methyl-1-butene, $\bigcirc: 2$-Methyl-2-butene

きく異なるので，共二量化反応と二量化反庆と比较するために，

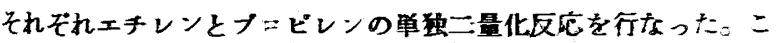
こではニッケルとタングステンの原子比を変えた場合のェチ～ ン,ブロピレンおのおのの二量化反店の活性およひ生成物の分布 を調べた。結果をそれぞれ图5，6に示す。因5に示したエチレ ンの二量化反底の結果から、ブテン中のィソブテンはこれらの永

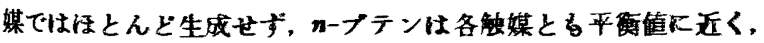
二重結合の異性化が速いことがかかる。また $\mathrm{WO}_{3}-\mathrm{Al}_{2} \mathrm{O}_{3}$ ではエ チレンの二量化は起こらなかったっまたこの条件下では，WOs $\mathrm{Al}_{2} \mathrm{O}_{3}$ 触媒を除く他の 4 種の触煤では三量化す起こっており，人 キセンの生成が双られる。

つきにプロビレンの二量化であるが, 图6に示したとおり

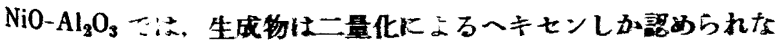
かったが，タングステンの害台が增如するにつれて二量化への勘 択率は娍少し，他の生成物であるブテン、ベンテン碩が増妿す る。これは持そらくプロピレンの二量化によって生成したへキを ンの分解生成物であろうこ思われる。目には示さなかったが、こ れらの生成物の他尺ェチンンる生成している。

以上いろいろの触某を用いてエチンンだけ，プロビレンだけ，

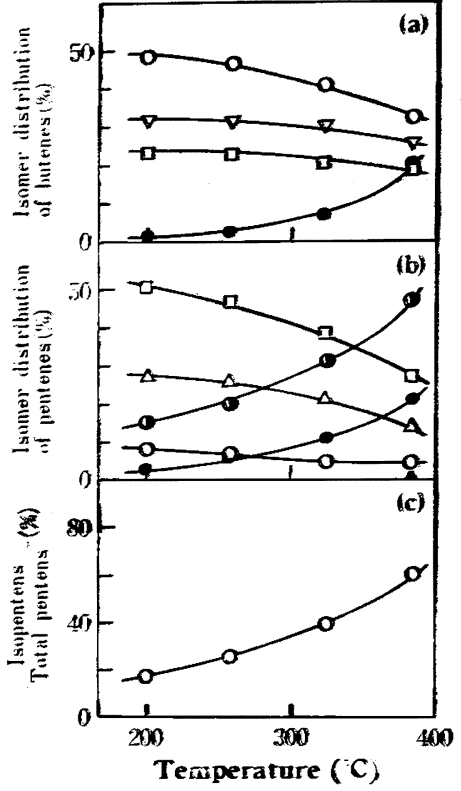

Fig. 4 The effect of the reaction temperature on butenes and pentenes produced

Catalyst : $\mathrm{N}_{i}: W=A l=25: 2.5: 95$, Catalyst volume : $10 \mathrm{ml}$, Feed rate $: 30 \mathrm{ml} / \mathrm{min}$, Mole ratio of reactants : $\mathrm{C}_{2} \mathrm{H}_{4} / \mathrm{C}_{3} \mathrm{H}_{6}=1$

(a) : Butenes

$\square$ : 1-Butene, $O$ : trans-2-Butene, $\nabla$ : cis-2-Butene,

: Isobutene

(b): : Pentenes

$O: 1-P e n t e n e, \square:$ trans-2-Pentene, $\Delta:$ cis-2-Pentene, :2-Methyl-1-butene, $D: 2$-Methyl-2-butene, $\boldsymbol{\Delta}:$ 3-Methyl-1-butene

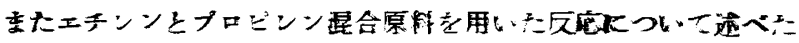

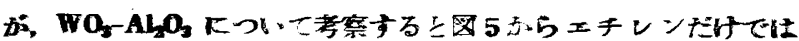

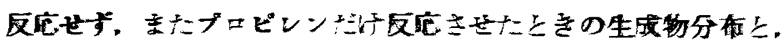

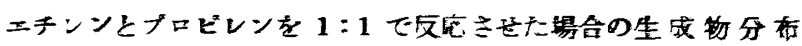

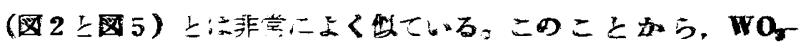

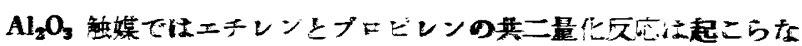
いと考えられ、エチンンンブロビンンを $1: 1$ で反店させた場合 の生成物山、ブニビレンだけの反她生成物であり，エチンン流 店しこい店い上思かれる。

\section{3 ヘンンテンの異性化反店}

二量化，共二量化元応の結果から，生成物でるブテン，ベン

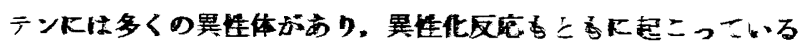
と思われる：其二量化父沈によって生成したベンテンの初䪶生成

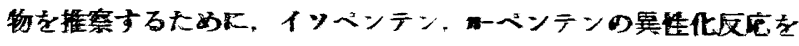
水った。

3.3.1 1ソベンテンの翼情化反庞 : 3-

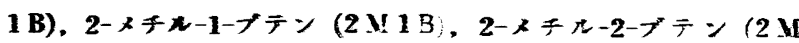

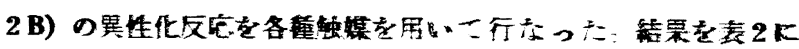

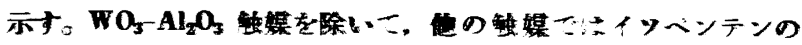

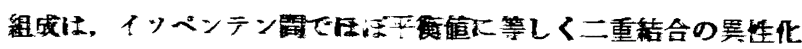

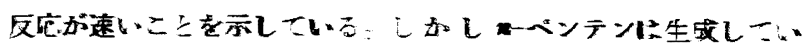

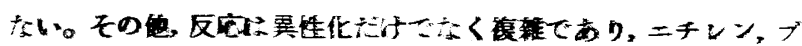

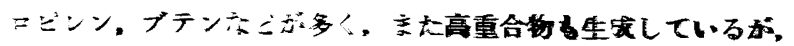


ここではとくにペンテンだけに注目したっこの結果, イソベン テンの異性化反応による生成物分布（n-ヘンテンが生成していな い）と共二量化反応により生成したベンテンの異性体分布（図2）

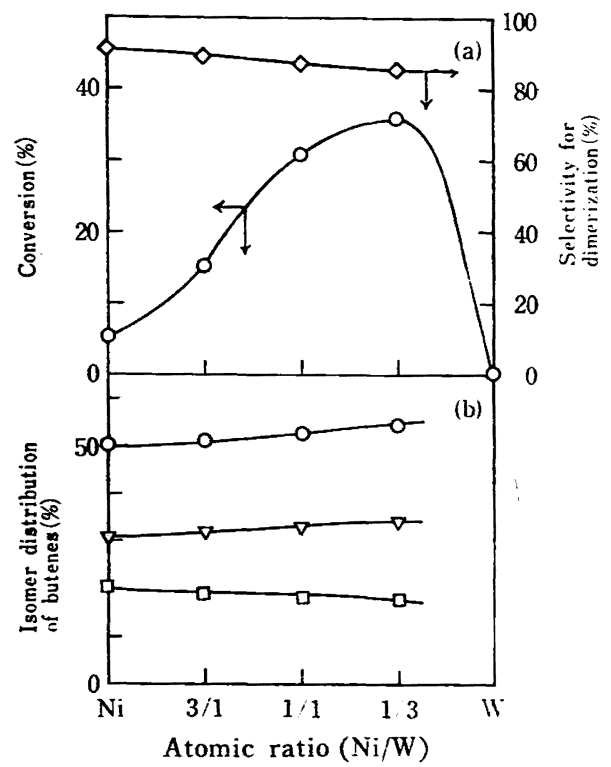

Fig. 5 The effect of catalyst composition on conversion and selectivity for the dimerization of ethylene

Catalyst : $(\mathrm{Ni}+\mathrm{W}): \mathrm{Al}=5: 95$, Catalyst volume $: 10 \mathrm{ml}$, Feed rate $: 30 \mathrm{ml} / \mathrm{min}$, Mole ratio of reactants $: \mathrm{C}_{2} \mathrm{H}_{4} /$ $\mathrm{C}_{3} \mathrm{H}_{6}=1$

(a):

$\bigcirc:$ Conversion, $\diamond:$ Selectivity

(b) : Butenes

$\square$ : 1-Butene, $O$ :trans-2-Butene, $\nabla:$ cis-2-Butene

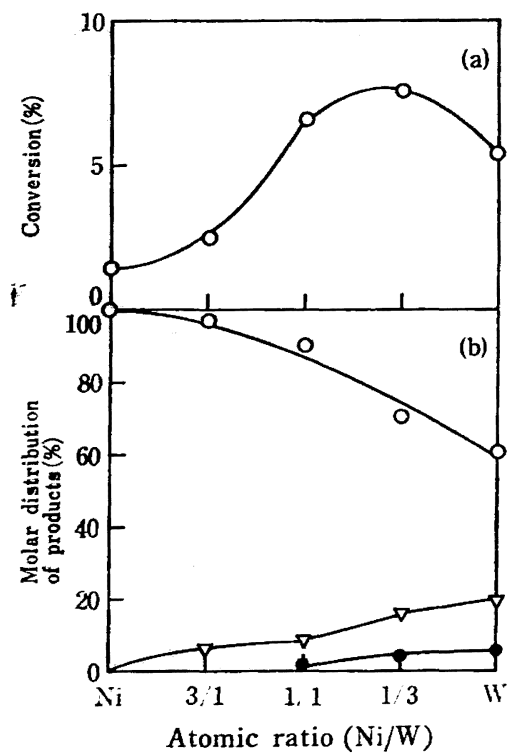

Fig. 6 The effect of catalyst composition on conversion and selectivity for the dimerization of propylene

Catalyst : $(\mathrm{Ni}+\mathrm{W}): \mathrm{Al}=5: 95$, Catalyst volume $: 10 \mathrm{ml}$, Feed rate $: 30 \mathrm{ml} / \mathrm{min}$, Mole ratio of reactants $: \mathrm{C}_{2} \mathrm{H}_{4} /$ $\mathrm{C}_{3} \mathrm{H}_{6}=1$, Reaction temperature : $200^{\circ} \mathrm{C}$

$\mathrm{O}:$ Hexenes, $\mathrm{:}$ Pentenes, $\nabla:$ Butenes
と大きく異なり，共二量化による初期生成物はイソヘンテンでは ないと思われる。このペンテンの異性化反灾で,ささらに興味があ る結果は, $\mathrm{WO}_{3}-\mathrm{Al}_{2} \mathrm{O}_{3}$ 触媒による一連のイソペンテンの反応結 果である。2 M $1 \mathrm{~B}, 2 \mathrm{M} 2 \mathrm{~B}$ に対しては，ほ汇平衡值に等しく $3 \mathrm{M} 1 \mathrm{~B}$ だけが非常に異性化の速度が遅い。これから $\mathrm{WO}_{3}-\mathrm{Al}_{2} \mathrm{O}_{3}$ による異性化は,

$$
2 \mathrm{M} 2 \mathrm{~B} \approx 2 \mathrm{M} 1 \mathrm{~B} \gg 3 \mathrm{M} 1 \mathrm{~B}
$$

であり,この序列はカルボニウムイオン機棈を考え,つまりカル ボニウムイオンの安定性の序列は

$$
\text { tert }-\mathrm{C}^{+}>\sec -\mathrm{C}^{+}>\text {pri- } \mathrm{C}^{+}
$$

である。

いまつぎのことを考吝れば,

Table 2 The composition of products from the isomerization of isopentenes

Reaction conditions -

Catalyst volume : $10 \mathrm{ml}$, Feed rate $: 30 \mathrm{ml} / \mathrm{min}$,

Partial pressure of isopentene : $0.03 \mathrm{~atm}$ in $\mathrm{N}_{2}$

$3 \mathrm{M} 1 \mathrm{~B} \quad 2 \mathrm{M} 1 \mathrm{~B} \quad 2 \mathrm{M} 2 \mathrm{~B}$

NiO- $\mathrm{Al}_{2} \mathrm{O}_{3} \quad$ Near equil. ${ }^{\text {a) }}$ Near equil. Near equil. $\mathrm{NiO}-\mathrm{WO}_{3}-\mathrm{Al}_{2} \mathrm{O}_{3} \quad " \quad "$ $\mathrm{WO}_{3}-\mathrm{Al}_{2} \mathrm{O}_{3} \quad$ Not equil. ${ }^{b)} "$ "

a) For example, $3 \mathrm{M} 1 \mathrm{~B}: 6.2 \%, 2 \mathrm{M} 1 \mathrm{~B}: 18 \%, 2 \mathrm{M} 2 \mathrm{~B}$ : $75.8 \%$ (in the case of isomerization of $3 \mathrm{M} 1 \mathrm{~B}$ on NiO$\mathrm{Al}_{2} \mathrm{O}_{3}$ ).

b) $3 \mathrm{M} 1 \mathrm{~B}: 93.1 \%, 2 \mathrm{M} 1 \mathrm{~B}:$ trace, $2 \mathrm{M} 2 \mathrm{~B}: 6.9 \%$.

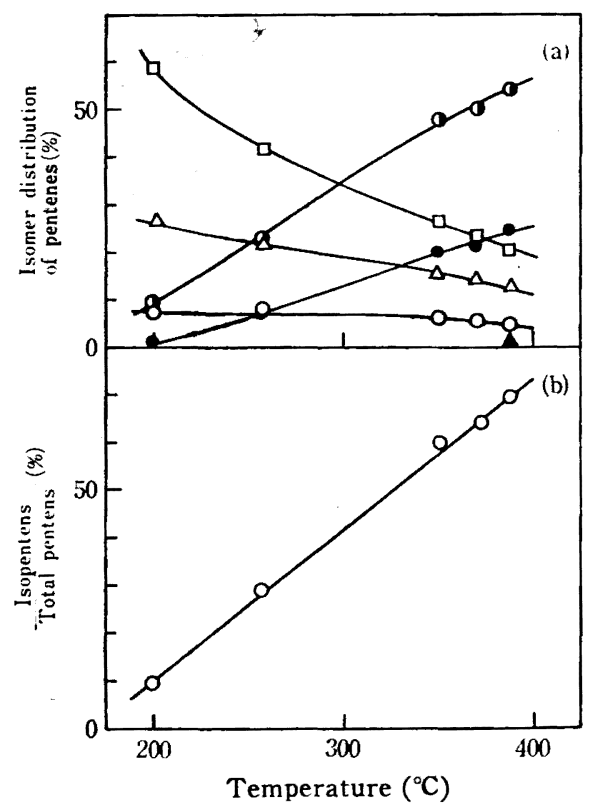

Fig. 7 The effect of the reaction temperature on the isomerization of 1-pentene

Catalyst : $\mathrm{Ni}: \mathrm{W}: A \mathrm{l}=2.5: 2.5: 95$, Catalyst volume : $10 \mathrm{ml}$, Feed rate $: 30 \mathrm{ml} / \mathrm{min}$, Partial pressure of 1 -pentene : $0.03 \mathrm{~atm}$ in $\mathrm{N}_{2}$

$\bigcirc$ : 1-Pentene, $\square:$ trans-2-Pentene, $\triangle$ : cis-2-Pentene, : 2-Methyl-1-butene, 1 :2-Methyl-2-butene, $\Delta: 3$ Methyl-1-butene 


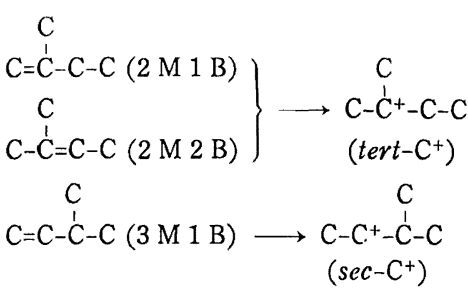

となり，カルボニウムイオンの生成しやすさと一致する。またこ の事実は $\mathrm{WO}_{3}-\mathrm{Al}_{2} \mathrm{O}_{3}$ を用いた場合のエチレンとプロピレンの反 応性がエチレンよりプロピレンの方が大きいということもカルボ ニウムイオン機構で説明でき，NiO を含む他の触媒とくらべて反 応機構が異なることがらかがわれる。

3.3.2 1-ペンテンの異性化反応：1-ペンテンの巽性化反応を $200 \sim 390^{\circ} \mathrm{C}$ の温度範囲で行なった。用いた触媒は $\mathrm{NiO}-\mathrm{WO}_{3^{-}}$ $\mathrm{Al}_{2} \mathrm{O}_{3}$ である。結果を図 7 に示す。反応温度の上昇とともにイソ ペンテンの組成が多くなり，各温度に拈けるペンテンの組成が図 3で示した結果とよく似ている。これからエチレンとプロピレン の共二量化反応によって生成したペンテン中のイソペンテンが反 応温度とともに増加するのは，初期に $n$-ペンテンが生成し，つ いで骨格異性化によってイソペンテンが生成するものと思われ る。

\section{4 水の被毒効果}

二量化反応に用いられるニッケル系触媒では, 少量の水によっ て失活することが報告采）されている。本実験に用いた触媒も同様
で少量の水によって被毒され，触媒の処理温度が低い場合や $\left(200^{\circ} \mathrm{C}\right.$ 以下 $), 400^{\circ} \mathrm{C}$ で堂素処理したのち, 水を添加すると活性 はほとんどなかった。

\section{4 総括}

（1）エチンンとプロピレンの共二量化反応を気相常圧流通法 を用い, 反応温度 $200 \sim 390^{\circ} \mathrm{C}, S V=120 \sim 550 \mathrm{hr}^{-1}$ で行ない, 酸化ニッケルー酸化タングステンーアルミナがこの反応に高活性を 示すことを見いだした。

（2）酸化タングステン-アルミナは，プロピレンの二量化反 応には活性を示すが，エチレンとプロピレンの共二量化反応には 不活性である。

（3）この反応の生成物であるペンテンは，多くの異性体を含 むが，これは共二量化によって生成した初期生成物である $n$-ペ ンテンの異性化によるもので，二重結合の異性化反応の速度は非 常に速いことを確認した。

（4）ニッケルを含む触媒では，エチレンの方がプロピレンよ り反応性の大きいことから， hard な酸上で反応が起こるとは考 えにくく、ニッケルでの soft な酸上で反応が進行するすのと思 われる。これに対し，タングステンーアルミナでは, イソペンテ ンの異性化反応で示した結果と，プロピレンの方がェチレンより 反応性の大きいことから，オレフィンの吸着型はカルボニウムイ オン型であると思われる。

\section{The Codimerization of Propylene with Ethylene over $\mathrm{NiO}-\mathrm{WO}_{3}-\mathrm{Al}_{2} \mathrm{O}_{3}$}

Atsuo Kobayashi and Etsuro Echigoya

Department of Chemical Engineering, Tokyo Institute of Technology ; Ookayama, Meguro-ku, Tokyo, Japan

The codimerization reaction of propylene with ethylene on various solid catalysts containing nickel and/or tungsten has been investigated under atmospheric pressure at the temperature range of $200 \sim 390^{\circ} \mathrm{C}$. Both $\mathrm{NiO}-\mathrm{Al}_{2} \mathrm{O}_{3}$ and $\mathrm{NiO}-\mathrm{WO}_{3}-\mathrm{Al}_{2} \mathrm{O}_{3}$ were effective catalysts for codimerization of propylene with ethylene, while $\mathrm{WO}_{3}-\mathrm{Al}_{2} \mathrm{O}_{3}$ was inactive. On the basis of the results of the isomerization reaction of 1 -pentene and isopentenes, it was suggested that the initial products formed by codimerization were mainly $n$-pentenes, and isopentenes were secondary products resulted from skeltal isomerization of $n$-pentenes.

Most of product was dimer in the reaction of ethylene or propylene over these catalysts. Their activities were as follows;

$$
\begin{aligned}
& \text { For ethylene : } \mathrm{NiO}-\mathrm{WO}_{3}-\mathrm{Al}_{2} \mathrm{O}_{3}>\mathrm{NiO}-\mathrm{Al}_{2} \mathrm{O}_{3} \gg \mathrm{WO}_{3}-\mathrm{Al}_{2} \mathrm{O}_{3} \approx 0 \\
& \text { For propylene : } \mathrm{NiO}-\mathrm{WO}_{3}-\mathrm{Al}_{2} \mathrm{O}_{3}>\mathrm{WO}_{3}-\mathrm{Al}_{2} \mathrm{O}_{3}>\mathrm{NiO}-\mathrm{Al}_{2} \mathrm{O}_{3}
\end{aligned}
$$

Besides dimerization, both double bond shift and skeletal isomerization were also observed on these catalysts. 